\title{
Microhabitat Use and Population Structure of a Chinese Kissing Loach, Leptobotia tchangi, in the North Tiaoxi River, China
}

\author{
Liangliang Huang ${ }^{*}$, Jianhua Li ${ }^{2}$, Yuichi Kano ${ }^{3}$, Tatsuro Sato ${ }^{3}$, Jyunichi Kitamura ${ }^{4}$, \\ Yukihiro Shimatani ${ }^{3}$, Zhiqiang $\mathrm{Wu}^{1}$ \\ ${ }^{1}$ Guangxi Scientific Experiment Center of Mining, Metallurgy and Environment, Guilin University of Technology, \\ Guilin, China \\ ${ }^{2}$ Key Laboratory of Yangtze River Water Environment, Ministry of Education, Tongji University, \\ Shanghai, China \\ ${ }^{3}$ Department of Urban and Environmental Engineering, Graduate School of Engineering, Kyushu University, \\ Fukuoka, Japan \\ ${ }^{4}$ Mie Prefectural Museum, Mie, Japan \\ Email: ${ }^{*}$ llhuang@glut.edu.cn
}

Received 11 March 2014; revised 11 April 2014; accepted 18 April 2014

Copyright (C) 2014 by authors and Scientific Research Publishing Inc.

This work is licensed under the Creative Commons Attribution International License (CC BY).

http://creativecommons.org/licenses/by/4.0/

c) (i)

Open Access

\section{Abstract}

Fundamental ecological information on the Chinese kissing loach (Leptobotia tchangi) was collected in the North Tiaoxi River, China, in September 2010. The length-frequency distribution calculated using FiSAT software showed the population structure of this kissing loach could be classified into four age groups suggesting that the life span of the loach should be 3 - 4 years. A stepwise multiple linear regression analysis revealed that the density of this kissing loach was significantly and positively correlated with water velocity, while the body size was significantly and positively correlated with river bed pebble size. It suggested that water velocity and variation of pebble size play important roles in the full life history of this kissing loach. Thus, maintenance of the rapid current and variety of substrate are essential for the conservation of this species under the present conditions in the river, which also can support river restoration being in harmony with survival of this kissing loach.

\section{Keywords}

Biodiversity Conservation, Fish Population, Riffle-Pool Structure, Microhabitat

\footnotetext{
${ }^{*}$ Corresponding author.
}

How to cite this paper: Huang, L.L., et al. (2014) Microhabitat Use and Population Structure of a Chinese Kissing Loach, Leptobotia tchangi, in the North Tiaoxi River, China. Open Journal of Ecology, 4, 337-345. 


\section{Introduction}

Botiids are one of the beloved groups of fishes for the aquarists and amateur ichthyologists due to their attractive and beautiful colours and interesting shapes of bodies [1]. However, with the destruction of their habitats in rivers, kissing loach (Parabotia curta) has been recognized as a critically endangered species in Japan since 2004 [2]-[4]. Another kissing loach, Leptobotia elongata, has also been listed as endangered species in China [5] [6]. For Botiidae, including the kissing loach, biological information such as development, growth, reproduction and genetic diversity, have been reported [7]-[10]. However, a dispute in this family's taxonomy still exists in China because of overlapping distribution range among species and the highly variable morphology of their different life stages [1] [11] [12].

Environmental variables, such as depth, velocity, substrate and conductivity have been considered to be important for stream-resident fishes [13]-[15]. Specialist species are often considered to be the "great losers" of the past and current global changes, and trends in the abundance of these species are used as indicators of unsustainable development at national and international scales [16] [17]. To implement appropriate conservation measures for any species, knowledge of the natural biology of the species in question is essential [18].

Leptobotia tchangi (Botiidae) is an endemic freshwater species around Tianmu Mountains in China [19]-[21]. It only inhabits in the middle-upper reaches of East Tiaoxi River, which originated from Tianmu Mountains, and the altitude of studied reach is around $60 \mathrm{~m}$. Nevertheless, the exact biology of L. tchangi has been poorly understood. This is the first study on the microhabitat preference and population structure of L. tchangi in its natural habitat, and this study is designed to: 1) determine the environmental variables that affect habitat use by different stages of $L$. tchangi and; 2) develop a microhabitat preference index for use in the conservation and management of this species.

\section{Material and Methods}

\subsection{Study Area}

The mountain channel, locally named the North Tiaoxi River, is one of tributaries of the Tiaoxi River which is the largest river flowing into Taihu Lake and lies between 119³7'30"-11957'42"E and 30²2'44"-30³3'32"N. North Tiaoxi River originates in Shimen Mountain in the East Tianmu Mountains, and it has a catchment of $310.4 \mathrm{~km}^{2}$, and its overall length is $46.5 \mathrm{~km}$ to its confluence with the East Tiaoxi River with gradient of approximate 1/100. The North Tiaoxi River is composed of three main tributaries, namely the Baizhang Stream, the Luniao Stream and the Taiping Stream (Figure 1). The stream's substratum originates mostly the weathering

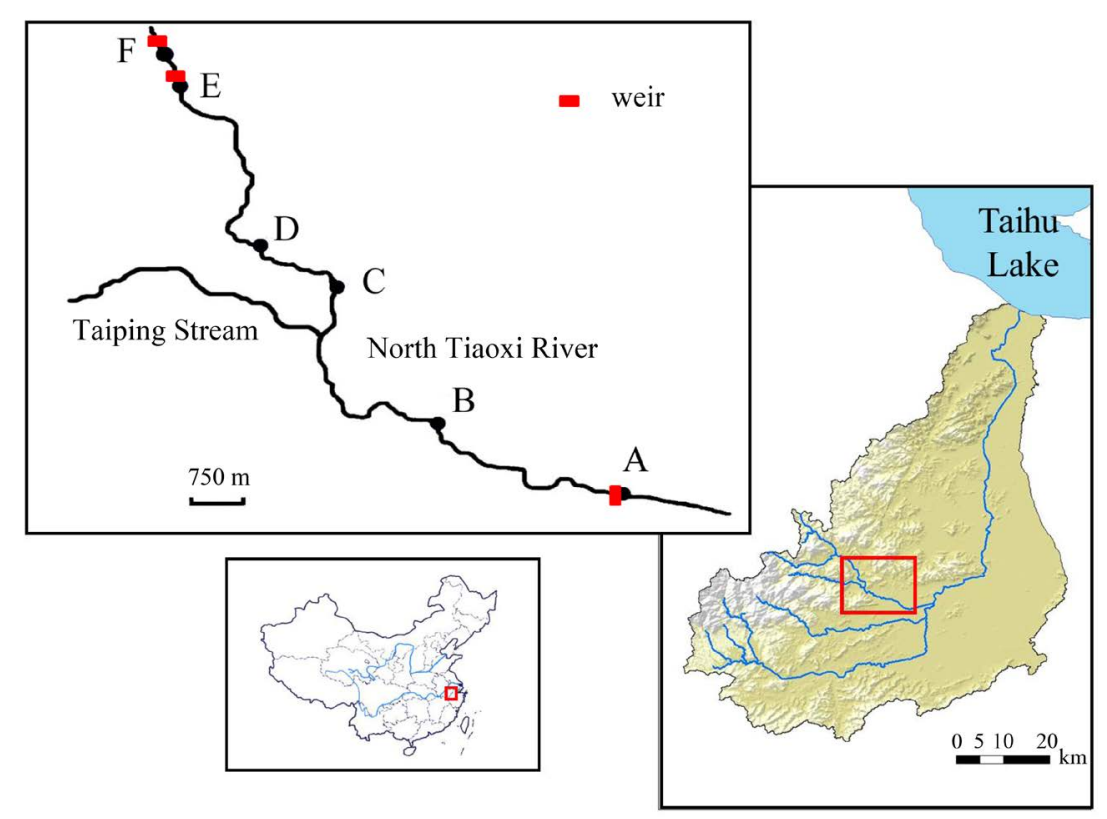

Figure 1. Sampling sites of $L$. tchangi in the North Tiaoxi River. 
and erosion of sandstones that form the valley and can be characterised as fine to coarse sand, gravel, cobbles and boulders. The annual precipitation is about $1460 \mathrm{~mm}$ and the catchment has a humid subtropical climate [22]. In recent decades, the North Tiaoxi River has been drastically modified for agricultural and domestic use [19]. Levees and weirs have been constructed in several sections of the river which have resulted in changes in flow velocities. Furthermore, the North Tiaoxi River has been utilized for numerous anthropogenic activities such as embankment and drift [21]. The physico-chemical characteristics in the study sites is summarized in Table 1.

\subsection{Sampling Methods}

The survey was conducted at six sites in the North Tiaoxi River (Figure 1; Sites A-F) from 18th to 26th September, 2010. About 4 - 10 sub-sites were established each site so that the local conditions were roughly equal within the respective sub-sites (Table 2). The fish samples were collected with an electrofisher (LR-24, SmithRoot, Vancouver, WA; Voltage: $200 \mathrm{~V}$ ) at each sub-site. At last, 35 sub-sites were selected totally and the area of sub-sites was from 6.0 to $46.2 \mathrm{~m}^{2}$. Although the "block-net" has been reported to be effective for the electrofishing [23], block-net was not applied in this study because the river was too large to enclose the whole subsite area. Alternatively, 5 - 7 hand nets were used to prevent the escape of the fish, which were set beneath the electrofishing points. The one-pass electrofishing with roughly 20 minutes $/ 10 \mathrm{~m}^{2}$ was conducted for each subsite because multiple-pass electrofishing might exert adverse effect on L. tchangi and other fishes [24]-[26]. However, to estimate the capture rate of the electrofishing for $L$. tchangi, electrofishing was conducted six times at one sub-site in site B. The catchment rate was $73.8 \% \pm 3.1 \%$ (Mean \pm SE) by the DeLury method, which showed one-pass electrofishing was valid in this study. All captive individuals of $L$. tchangi were counted and measured their total length (TL) until $1 \mathrm{~mm}$ and then were released back to the river.

\begin{tabular}{|c|c|c|c|c|}
\hline & Mean & SD & Min & Max \\
\hline Water depth (cm) & 25.22 & 7.84 & 16.13 & 52.00 \\
\hline Current velocity $(\mathrm{cm} / \mathrm{s})$ & 45.17 & 37.19 & 1.57 & 138.78 \\
\hline Pebble size (cm) & 16.50 & 7.75 & 7.29 & 30.14 \\
\hline Water temperature $\left({ }^{\circ} \mathrm{C}\right)$ & 26.13 & 3.45 & 21.60 & 30.20 \\
\hline Dissolved oxygen (mg/L) & 6.29 & 1.54 & 4.28 & 8.79 \\
\hline Conductivity ( $\mu \mathrm{s} / \mathrm{cm})$ & 170.22 & 37.97 & 98.50 & 195.40 \\
\hline $\mathrm{pH}$ & 7.66 & 0.60 & 6.91 & 8.40 \\
\hline Turbidity (NTU) & 13.99 & 10.48 & 4.36 & 32.00 \\
\hline
\end{tabular}

Table 2. Sampling protocol at each site and its habitat characteristics.

\begin{tabular}{cccccccccc}
\hline \multirow{2}{*}{ Site } & \multirow{2}{*}{$\begin{array}{c}\text { No. of } \\
\text { sub-sites }\end{array}$} & \multicolumn{3}{c}{ Survey area $\left(\mathrm{m}^{2}\right)$} & \multicolumn{5}{c}{ Habitat characteristics (mean) } \\
\cline { 3 - 9 } & Min. & Mean & Max. & T & DO & Con. & pH & Turb. \\
\hline A & 5 & 6 & 13.8 & 24.2 & 26.8 & 4.28 & 188.2 & 6.91 & 5.8 \\
B & 5 & 13.6 & 16.2 & 18.9 & 22.5 & 6.48 & 156.1 & 7.66 & 4.36 \\
C & 6 & 19.1 & 25.7 & 28.8 & 30.2 & 8.79 & 195.4 & 8.4 & 9.38 \\
D & 5 & 14.3 & 21.7 & 30 & 21.6 & 6.25 & 98.5 & 7.65 & 12.1 \\
E & 4 & 14.3 & 24.4 & 34.4 & 29.3 & 6.78 & 191.6 & 8.26 & 20.3 \\
F & 10 & 18 & 29 & 46.2 & 26.4 & 5.13 & 191.5 & 7.1 & 32 \\
\hline
\end{tabular}

Note: T: Water Temperature $\left({ }^{\circ} \mathrm{C}\right)$; DO: Dissolved Oxygen (mg/L); Con.: Conductivity ( $\left.\mu \mathrm{s} / \mathrm{cm}\right)$; Turb.: Turbidity (NTU). 
Three environmental variables for microhabitat were measured at each sub-site such as water depth, water velocity, and substrate size of river bed [15]. The three parameters were measured every three steps by walking zigzag at each sub-site [27]. For instance, water velocity was measured near the bottom where the kissing loach lived, while substrate size was measured the intermediate axis (width) of pebble which was selected randomly [28] [29]. These three parameters were measured 8 - 11 times each sub-site, and the values of each factor were averaged for each sub-site.

\subsection{Data Analysis}

To understand whether the L. tchangi density was correlated with the three parameters (depth, velocity and/or pebble size), generalized linear mixed model (GLMM) was conducted, in which the depth, velocity and pebble size were the explanatory variables and the relative density (individuals $/ \mathrm{m}^{2}$ ) was the dependent variable. The site was considered as the random effect. The stepwise selection was applied for the choice of effective predictors, in which threshold of $P$ value (Pin-out) was set 0.05 . For the implementation of GLMM, the statistical software "R" (version 2.92) was used and the function "glmmML" (glmmML package) was applied where the Poisson distribution was applied.

To understand whether the body size of $L$. tchangi was correlated with the three parameters, similar analysis was conducted for average total length in respective sub-sites as dependent variable. The sub-sites where the number of $L$. tchangi was less than three individuals were removed in this analysis. For the implementation of the analysis of "R", the function "Ime" (package "nlme") was applied.

Many previous studies have divided fishes into different age groups or cohorts on the basis of length-frequency distribution calculated using FiSAT [30]-[32]. Bhattacharya's method to implement a FiSAT analysis was applied to identify the cohorts of $L$. tchangi with different length-frequency distribution [33]. The size-frequency distribution of $L$. tchangi was computed at a $5 \mathrm{~mm}$ interval.

\section{Results}

\subsection{Age Structure of L. tchangi Population in North Tiaoxi River}

The length-frequency distribution and the results of the model analysis were presented in Figure 2. These models were assumed to correspond to distinct age groups or cohorts. The length-frequency distribution in the present study could grouped into four categories including the age class 0 , age class 1 , age class 2 and age class 3 , and their borders were estimated to be the valley points between the population curves of neighbouring age classes. The total length of the age class 0 , age class 1 , age class 2 and age class 3 were $36.59 \pm 2.98 \mathrm{~mm}(\mathrm{M} \pm$ SD), $55.9 \pm 8.21 \mathrm{~mm}, 75.68 \pm 4.61 \mathrm{~mm}$ and $92.5 \pm 5.05 \mathrm{~mm}$, respectively (Table 3). Moreover, two individuals

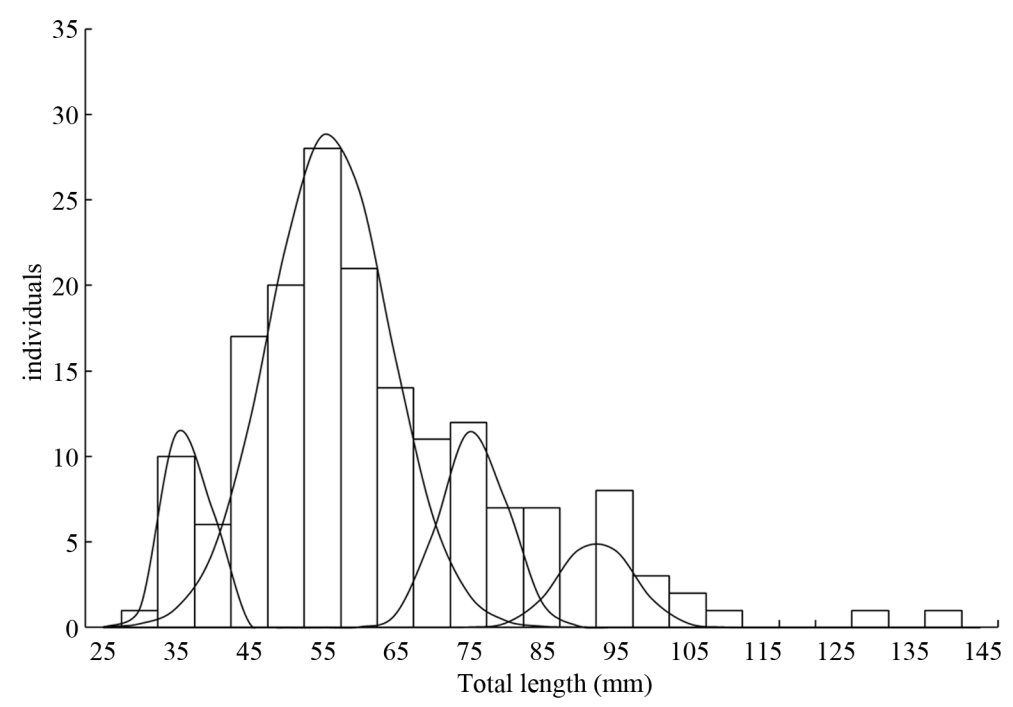

Figure 2. Length-frequency distribution of $L$. tchangi superimposed with normal curve determined by using Bhattacharya's methods. 
Table 3. Total length of $L$. tchangi for each age group in the North Tiaoxi River.

\begin{tabular}{ccccc}
\hline & \multicolumn{4}{c}{ Age group } \\
\cline { 2 - 5 } & Class 0 & Class 1 & Class 2 & Class 3 \\
\hline Total length (mm) (M \pm SD) & $36.59 \pm 2.98$ & $55.90 \pm 8.21$ & $75.68 \pm 4.61$ & $92.50 \pm 5.05$ \\
Individuals & 18 & 108 & 24 & 12 \\
\hline
\end{tabular}

were located outside these four cohorts (Figure 2), which might indicate that few individuals can survive more than 4 years. The number of young individuals (age class 0,1 ) was much more than those older individuals (age class 2, 3) (Table 3).

\subsection{Microhabitat Preference for L. tchangi}

The results of the stepwise multiple regression showed that the density of $L$. tchangi was significantly and positively correlated with water velocity only (Figure 3, Table 4), while water depth and pebble size were removed by step forward selection which mean the density of L. tchangi was insignificantly related to water depth and pebble size. However, the results of the stepwise multiple regression showed that the body size was significantly and positively correlated with river bed pebble size (Figure 4, Table 4), while water depth and velocity were removed by step forward selection. The results of the stepwise multiple regression showed the fish at different stages were significantly correlated to different environmental variables (Table 5). Water depth and pebble size were removed by step forward selection for age class 0 and age class 1 . However, age class 0 preferred the site of slow velocity, while age class 1 preferred the site of high velocity (Table 5). Water depth and velocity were removed by step forward selection for age class 2 and age class 3, and the individuals at those two age classes preferred to sites of large pebble size (Table 5). Therefore, large body size of $L$. tchangi preferred to large pebble size, whereas the small body size had a preference of riparian zone in where was small water velocity, and medium body size prefers sites of high velocity.

\section{Discussion}

This is the first study on the microhabitat preference of stream fish in China. The number of individuals decreased rapidly from the age class 3 in the present study (Figure 2), suggesting that the life span of this species should be 3 - 4 years, although a few individuals may survive to more than 4 years (Figure 2). Moreover, the population distribution suggested that the population of L. tchangi in the North Tiaoxi River was a stable population (Table 3). Many studies have shown intraspecific differences between populations in terms of life-history traits, including age at first reproduction and reproduction life span, which can be related to environmental variation or food availability [34] [35]. In previous studies of kissing loach in Japan, the spawning behaviour and the rapid larval development of $P$. curta has been adaptation for the use of temporary waters as a spawning ground and the rise in water level and the consequent formation of temporary waters appears to be crucial triggers for reproduction of the kissing loach, which can be used for conservation of kissing loach in Japan [2] [3] [36].

In addition, $L$. tchangi at different stages prefer to different habitat types. The distribution of L. tchangi in the North Tiaoxi River was only between site F and near site A [19] [20], and it did not distribute in Taiping stream. It might be different habitat types, such as riffle, pool, distribute continuously in the North Tiaoxi River, whereas "pool" occupied most Taiping stream. The height of weir over site F was more than $1.5 \mathrm{~m}$ without gap in the weir which made by concrete. It can stop this kissing loach move to the upper reaches. However, the height of weir over site A was only $0.5 \mathrm{~m}$ with gap in the weir, which can make the kissing loach, as well as other species pass the weir easily.

In the North Tiaoxi River, L. tchangi at age class 0 preferred clam water at riparian area, and then they moved to the areas with rapid current at age class 1 , and they moved to the areas with large pebble size in rapid areas ultimately at age class 2 and class 3. It suggested that calm water at riparian area could provide a stable environment for development and growth of age class 0 or fertilized eggs, and large pebble size area could provide a refuge for adult fish [36]. It suggested that the absolute amount of the pebbles might affect the relationship between fish size and pebble size. For example, larger fish might out-compete smaller fish for the large pebble in streams with less large pebbles in the study stream. Slavík et al. have also shown the same substratum prefe- 


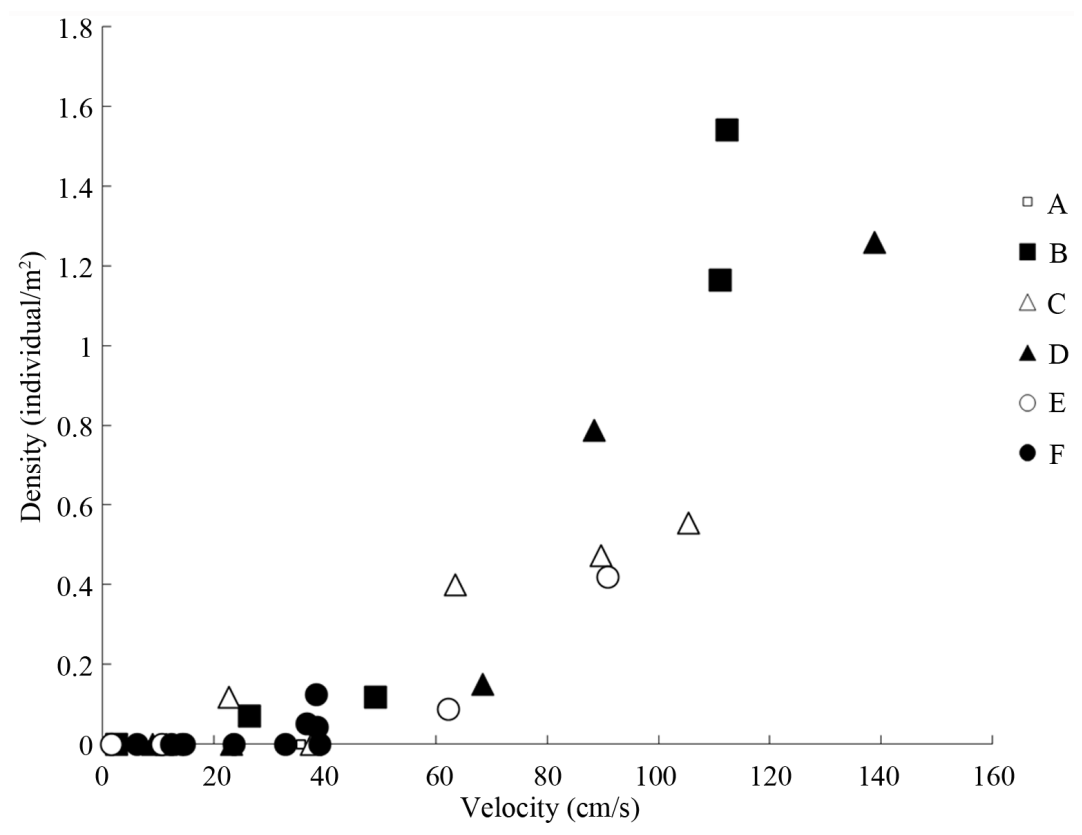

Figure 3. The relationship between fish density of $L$. tchangi and water velocity in different sites.

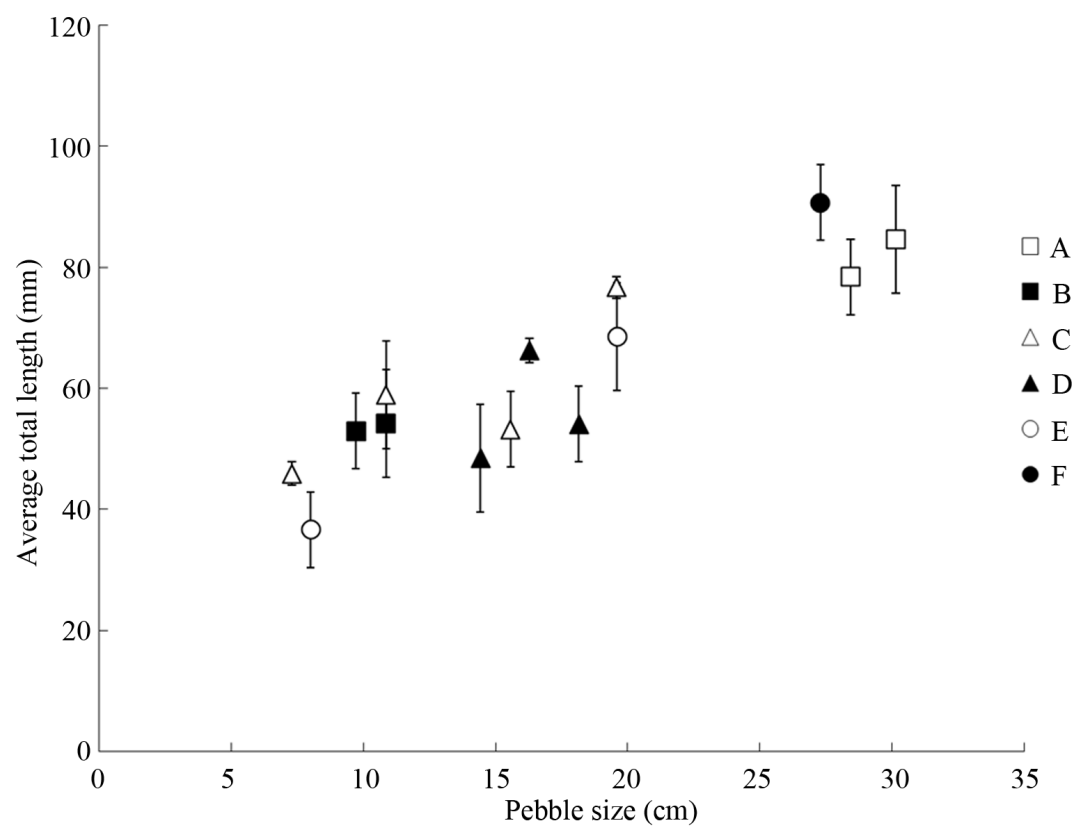

Figure 4. The relationship between pebble size and average total length of $L$. tchangi in different sites.

Table 4. Results of stepwise multiple regression analysis for fish density and total length of $L$. tchangi.

\begin{tabular}{ccccc}
\hline & Intercept $( \pm$ SE) & Water velocity $[\mathrm{m} / \mathrm{s}]( \pm$ SE) & Pebble size $[\mathrm{cm}]( \pm$ SE $)$ & $\mathbf{R}$ \\
\hline Density & $(-4.12 \pm 0.29)^{* * *}$ & $(3.52 \pm 0.30)^{* * * *}$ & & $\mathbf{0 . 8 1}$ \\
Total length & $(30.3 \pm 4.96)^{* * *}$ & & $(1.88 \pm 0.27)^{* * *}$ & $\mathbf{0 . 6 8}$ \\
\hline Note: ${ }^{* * *} P<0.001$. & & &
\end{tabular}


Table 5. Stepwise multiple regression analysis using total length of $L$. tchangi at different stages as dependent variables.

\begin{tabular}{ccccc}
\hline Age group & Intercept $( \pm$ SE) & Water velocity $[\mathrm{m} / \mathrm{s}]( \pm \mathrm{SE})$ & Pebble size $[\mathrm{cm}]( \pm \mathrm{SE})$ & $\mathrm{R}$ \\
\hline Class 0 & $(-3.15 \pm 0.27)^{* *}$ & $(-1.42 \pm 0.30)^{* *}$ & & 0.76 \\
Class 1 & $(65.86 \pm 3.41)^{* *}$ & $(0.10 \pm 0.03)^{* *}$ & & 0.57 \\
Class 2 & $(71.39 \pm 4.43)^{* *}$ & & $(0.48 \pm 0.21)^{*}$ & 0.66 \\
Class 3 & $(52.3 \pm 4.36)^{* *}$ & & $(0.87 \pm 0.26)^{*}$ & 0.59 \\
\hline
\end{tabular}

Note: ${ }^{*} P<0.05 ;{ }^{* *} P<0.01$.

rence for spined loach (Cobitis sp.) [37]. Some studies have suggested that habitat availability affected habitat preference of fish [15] [38]. Stream depth and water velocity could play an important role in microhabitat preference for fishes [13] [15] [39]. Voos and Lifton have suggested that bivariate habitat use of depth and velocity, because a single factor might not be enough to describe habitat use in complex ecosystems [40]. In the present study, neither of these two variables significantly related to the size of fish, whereas the significant relationship between fish density and water velocity, and the significant correlation between fish size and pebble size were revealed (Table 4). These results suggested that water velocity and substratum size should play an important role in the growth of this kissing loach.

L. tchangi is an endemic freshwater fish in the North Tiaoxi River [19]. The present study was focused on the microhabitat for living but not for the whole life stage of $L$. tchangi in the natural rivers. Therefore, the environmental variables such as physical-chemistry factors were not involved in this study. Characterising fish-habitat associations in streams have to be the first step in ecological restoration [41]. The present results including habitat use availability and preference, allowed us to identify the relative importance of environmental factors and to accurately describe preferred habitats of this kissing loach. In addition, as an endemic species, ecological specialization of $L$. tchangi in the North Tiaoxi River remains unclear. Therefore, study of reproduction characteristic, feeding habitat of $L$. tchangi, which is very important information for fish conservation, will be put into the schedule in the near future. River engineering exerts negative effect on fish diversity in the East Tiaoxi River watershed, especially for endemic species [20]. Consequently, river restoration, which involves habitat creation to match fish behaviour, may be beneficial to fish populations and compatible with river engineering.

\section{Conclusion}

The population structure of $L$. tchangi in the North Tiaoxi River could be classified into four age groups, which suggested that the life span of this kissing loach should be 3 - 4 years. Water velocity and variation of pebble size played important roles in the full life history of $L$. tchangi. For example, the density of $L$. tchangi was significantly and positively correlated with water velocity, while the body size was significantly and positively correlated with river bed pebble size. Thus, maintenance of the rapid current and variety of substrate are essential for the conservation of $L$. tchangi under the present conditions in the river, which also can support river restoration being in harmony with survival of this kissing loach.

\section{Acknowledgements}

This work was supported by National Natural Science Foundation of China (51379038) and the Program to Sponsor Teams for High Level of Innovation in Guangxi Institutions of Higher Learning (GuiJiaoRen 2013-38), Key Projects of Shanghai Science and Technology Commission (2010BAK69B16-1-3), Global COE Program (Ministry of Education, Culture, Sports, Science and Technology, Japan; Center of excellence for Asian conservation ecology as a basis of human-nature mutualism) and Research Institute for East Asia Environment (Kyushu University). We are deeply grateful to Yuan Ding, Jia Liu, Tomotaka Matsumoto, Tetsukazu Yahara for great field assistance. We also thank two anonymous reviewers for their helpful and insightful comments on our manuscript.

\section{References}

[1] Nalbant, T.T. (2002) Sixty Million Years of Evolution. Part One: Family Botiidae (Pisces: Ostariophysi: Cobitoidea). 
Travaux du Muséum National d' Histoire Naturelle "Grigore Antipa”, 44, 309-333.

[2] Abe, T., Kobayashi, I., Kon, M. and Sakamoto, T. (2007) Spawning Behavior of the Kissing Loach (Leptobotia curta) in Temporary Waters. Zoological Science, 24, 850-853. http://dx.doi.org/10.2108/zsj.24.850

[3] Abe, T., Kobayashi, I., Kon, M. and Sakamoto, T. (2007) Spawning of the Kissing Loach (Leptobotia curta) Is Limited to Periods Following the Formation of Temporary Waters. Zoological Science, 24, 922-926. http://dx.doi.org/10.2108/zsj.24.922

[4] Watanabe, K., Abe, T. and Iwata, A. (2009) Phylogenetic Position and Generic Status of the Japanese Botiid Loach. Ichthyological Research, 56, 421-425. http://dx.doi.org/10.1007/s10228-009-0128-8

[5] Yuan, Y., Yang, H., Gong, S. and Liang, Y. (2010) Threatened Fishes of the World: Leptobotia elongata Bleeker, 1870 (Bottiinae). Environmental Biology of Fishes, 87, 295-296. http://dx.doi.org/10.1007/s10641-010-9582-4

[6] Yue, P. and Chen, Y. (1998) China Red Data Book of Endangered Animals: Pisces. National Environmental Protection Agency, Endangered Species Scientific Commission, Science Press, Beijing. (in Chinese with English Summary)

[7] Liang, Y., Hu, X., Yu, C., Huang, D. and Chang, J. (2004) Postembryonic Development and Growth of Larval and Juvenile Elongate Loach Leptobotia elongata (Bleeker). Acta Hydrobiologica Sinica, 28, 96-100. (in Chinese with English Summary)

[8] Tang, Q., Liu, H., Mayden, R. and Xiong, B. (2006) Comparison of Evolutionary Rates in the Mitochondrial DNA Cytochrome b Gene and Control Region and Their Implications for Phylogeny of the Cobitoidea (Teleostei: Cypriniformes). Molecular Phylogenetics and Evolution, 39, 347-357. http://dx.doi.org/10.1016/j.ympev.2005.08.007

[9] Yin, J. (2006) The Development of Gonads and Germ Cells in Leptobotia elongata Bleeker (Thesis). School of Life Science, Southwest University, Chongqing. (in Chinese with English Summary)

[10] Watanabe, K., Takeshima, H., Iwata, A., Abe, T., Uehara, K., Kakioka, R., Kihira, D. and Nishida, M. (2008) Isolation and Characterization of 39 Microsatellite Loci in the Endangered Japanese Loach Leptobotia curta. Molecular Ecology Resources, 8, 145-148. http://dx.doi.org/10.1111/j.1471-8286.2007.01902.x

[11] Chen, Y. and Chen, Y. (2005) Secondary Sexual Characters, Pigmentary Zones of Gambetta and Taxonomical Revision the Genus Cobitis from China (Pisces, Cobitidae, Cobitinae). Acta Zootaxon Sinica, 30, 647-658. (in Chinese with English Summary)

[12] Chen, J. (1980) A Study on the Classification of Fishes in the Botiinae in China. Zoological Research, 1, 3-25. (in Chinese with English Summary)

[13] Copp, G.H. and Vilizzi, L. (2004) Spatial and Ontogenetic Variability in the Microhabitat Use of Stream-Dwelling Spined Loach (Cobitis taenia) and Stone Loach (Barbatula barbatula). Journal of Applied Ichthyology, 20, 440-451. http://dx.doi.org/10.1111/j.1439-0426.2004.00605.x

[14] Pekárik, L., Koščo, J. and Švátora, M. (2012) Reference Conditions for Fish Microhabitat Use in Foothill Streams: A Case Study on Undisrupted Carpathian Streams. River Research and Applications, 28, 369-376. http://dx.doi.org/10.1002/rra.1462

[15] Yu, S. and Lee, T. (2002) Habitat Preference of the Stream Fish, Sinogastromyzon puliensis (Homalopteridae). Zoological Studies, 41, 183-187.

[16] Devictor, V., Clavel, J., Julliard, R., Lavergne, S., Mouillot, D., Thuiller, W., Venail, P., Villéger, S. and Mouquet, N. (2010) Defining and Measuring Ecological Specialization. Journal of Applied Ecology, 47, 15-25. http://dx.doi.org/10.1111/j.1365-2664.2009.01744.x

[17] Smith, E.P. (1982) Niche Breadth, Resource Availability, and Inference. Ecology, 63, 1775-1681. http://dx.doi.org/10.2307/1940109

[18] Washitani, I. and Yahara, T. (1996) An Introduction to Conservation Biology: From Gene to Landscape. Bun Ichi, Tokyo. (in Japanese with English Summary)

[19] Li, J., Huang, L., Zou, L., Kano, Y., Sato, T. and Yahara, T. (2012) Spatial and Temporal Variation of Fish Assemblages and Their Association to Habitat Variables in a Mountain Stream of North Tiaoxi River, China. Environmental Biology of Fishes, 93, 403-417. http://dx.doi.org/10.1007/s10641-011-9928-6

[20] Li, J., Huang, L., Sato, T., Zou, L., Jiang, K., Yahara, T. and Kano, Y. (2013) Distribution Pattern, Threats and Conservation of Fish Biodiversity in the East Tiaoxi, China. Environmental Biology of Fishes, 96, 519-533. http://dx.doi.org/10.1007/s10641-012-0036-Z

[21] Sato, T., Kano, Y., Huang, L., Li, J. and Shimatani, Y. (2010) Assessment of River Environment in the East Tiaoxi Basin, China Using GPS-Logger, Google Earth and Landsat Images. Proceedings of River Technology, 16, 47-52. (in Japanese with English Summary)

[22] Chen, G., Hu, C., Cheng, X. and Wang, C. (2009) Analytic Study on Enhancement of Flood Control Capacity and Channel Improvement for Dongtiaoxi River. Water Resources and Hydropower Engineering, 40, 53-56. (in Chinese with 
English Summary)

[23] Simonson, T.D. and Lyons, J. (1995) Comparison of Catch per Effort and Removal Procedures for Sampling Stream Fish Assemblages. North American Journal of Fisheries Management, 15, 419-427. http://dx.doi.org/10.1577/1548-8675(1995)015<0419:COCPEA>2.3.CO;2

[24] Bateman, D.S., Gresswell, R.E. and Torgersen, C.E. (2005) Evaluating Single-Pass Catch as a Tool for Identifying Spatial Pattern in Fish Distribution. Journal of Freshwater Ecology, 20, 335-345. http://dx.doi.org/10.1080/02705060.2005.9664974

[25] Humpl, M. and Lusk, S. (2006) Effect of Multiple Electro-Fishing on Determining the Structure of Fish Communities in Small Streams. Folia Zoology, 55, 315-322.

[26] Reid, S.M., Yunker, G. and Jones, N.E. (2009) Evaluation of Single-Pass Backpack Electric Fishing for Stream Fish Community Monitoring. Fisheries Management Ecology, 16, 1-9. http://dx.doi.org/10.1111/j.1365-2400.2008.00608.x

[27] Bevenger, G.S. and King, R.M. (1995) A Pebble Count Procedure for Assessing Watershed Cumulative Effects. USDA Forest Service, Rocky Mountain Forest and Range Experiment Station, Res Pap RM-RP-319, 1-17.

[28] Harrelson, C.C., Rawlins, C.L. and Potyondy, J.P. (1994) Stream Channel Reference Sites: An Illustrated Guide to Field Technique. US Forest Service, Rocky Mountain Forest and Range Experiment Station, Fort Collins.

[29] Wolman, M.G. (1954) A Method of Sampling Coarse River-Bed Material. Transactions-American Geophysical Union, 35, 951-956. http://dx.doi.org/10.1029/TR035i006p00951

[30] Amin, S., Zafar, M.N. and Halim, A. (2008) Age, Growth, Mortality and Population Structure of the Oyster, Crassostrea madrasensis, in the Moheskhali Channel (Southeastern Coast of Bangladesh). Journal of Applied Ichthyology, 24, 18-25.

[31] Azevedo, J.M.N. and Simas, A.M.V. (2000) Age and Growth, Reproduction and Diet of a Sublittoral Population of the Rock Goby Gobius paganellus (Teleostei, Gobiidae). Hydrobiogia, 400, 129-135. http://dx.doi.org/10.1023/A:1004102723234

[32] Onikura, N., Nakajima, J., Kouno, H., Sugimoto, Y. and Kaneto, J. (2009) Habitat Use in Irrigation Channels by the Golden Venus Chub (Hemigrammocypris rasborella) at Different Growth Stages. Zoological Science, 26, 375-381. http://dx.doi.org/10.2108/zsj.26.375

[33] Gayanilo, F.C., Sparre, P. and Pauly, D. (2005) FAO-ICLARM Stock Assessment Tools II. Revised Version. User's Guide. Worldfish Center, Rome.

[34] Conover, D.O. (1992) Seasonality and the Scheduling of Life-History at Different Latitudes. Journal of Fish Biology, 41, 161-178. http://dx.doi.org/10.1111/j.1095-8649.1992.tb03876.x

[35] Matthews, W.J. (1998) Patterns in Freshwater Fish Ecology. Springer, New York. http://dx.doi.org/10.1007/978-1-4615-4066-3

[36] Iwata, A. (2006) Significance of Paddy Field Agriculture for the Existence of the Kissing Loach (Leptobotia curta). Japanese Journal of Conservation Ecology, 11, 133-141. (in Japanese with English Summary)

[37] Slavík, O., Mattas, D., Jiřinec, P., Bartoš, L. and Rebec, J. (2000) Substratum Selection by Different Sizes of Spined Loach Cobitis sp. Folia Zoology, 49, 167-172.

[38] Yu, S. and Peters, E.J. (1997) Use of Froude Numbers to Determine Habitat Selection by Fishes. Rivers, 6, 10-18.

[39] Watkins, M.S., Doherty, S. and Copp, G.H. (1997) Microhabitat Use by 0+ and Older Fishes in a Small English Chalk Stream. Journal of Fish Biology, 50, 1010-1024. http://dx.doi.org/10.1111/j.1095-8649.1997.tb01626.x

[40] Voos, K.A. and Lifton, W.S. (1988) Development of a Bivariate Depth and Velocity Suitability Function for Dolly varden (Salvelinus malma) Juveniles. In: Bovee, K.D. and Zuboy, J.R., Eds., Proceedings of a Workshop on the Development and Evaluation of Habitat Suitability Criteria, Fort Collins, 8-12 December 1986, Fish and Wildlife Service Biological Report, 88, 307-319.

[41] Bond, N.R. and Lake, P.S. (2003) Characterising Fish-Habitat Associations in Streams as the First Step in Ecological Restoration. Austral Ecology, 28, 611-621. http://dx.doi.org/10.1046/j.1442-9993.2003.t01-1-01317.x 